\title{
Molecular Structure of 1,2,5-Selenadiazolodibenzosubporphyrazinato- boron(III) Chloride and Influence of Perfluorination and Perchlorination on Its Spectral Properties
}

\author{
Mahmoud Hamdoush, ${ }^{a}$ Nikolay V. Somov, ${ }^{\text {b }}$ Svetlana S. Ivanova, ${ }^{a}$ \\ and Pavel A. Stuzhin ${ }^{\mathrm{a}}$ \\ ${ }^{a}$ Research Institute of Macroheterocycles, Ivanovo State University of Chemistry and Technology, 153000 Ivanovo, Russia \\ ${ }^{\mathrm{b}}$ N.I. Lobachevsky State University of Nizhni Novgorod, 603950 Nizhny Novgorod, Russia \\ ${ }^{\circledR}$ Corresponding author E-mail: stuzhin@isuct.ru
}

\begin{abstract}
Novel Se-containing heterocyclic subphthalocyanine analogue - (1,2,5-selenadiazolo)dibenzosubporphyrazinatoboron(III) chloride $3 \boldsymbol{a}$ was prepared by template cross-cyclomerization of 1,2,5-selenadiazolo-3,4-dicarbonitrile 1 and phthalonitrile $\mathbf{2 a}$ with $\mathrm{BCl}_{3}$ in p-xylene. Similar reactions of $\mathbf{1}$ and tetrafluoro- or tetrachlorphthalonitriles $(\mathbf{2} \boldsymbol{b}$ or $2 \boldsymbol{c}$ ) afford octafluorinated and octachlorinated subporphyrazines $\mathbf{3 b}$ and $\mathbf{3} \boldsymbol{c}$. The formation of $\mathbf{3 a - c}$ was established by MALDI-TOF mass-spectrometry and the structure of 3 a was determined by single crystal X-ray diffraction. Influence of halogenation on the spectral properties is discussed.
\end{abstract}

Keywords: Subphthalocyanine analogues, subporphyrazines, 1,2,5-selenadiazole, perfluorinated and pecrchlorinated derivatives, boron(III) complexes, crystal structure, UV-Vis spectra.

\section{Молекулярная структура 1,2,5-селенадиазолодибензо- субпорфиразинатобор(III) хлориАа и влияние перфторирования и перхлорирования на его спектральные свойства}

\author{
М. Хамдуш, ${ }^{a}$ Н. В. Сомов, ${ }^{\text {b }}$ С. С. Иванова, ${ }^{a}$ П. А. Стужин ${ }^{\text {a@ }}$

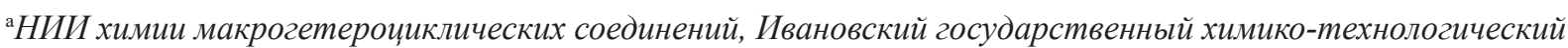 \\ университет, 153000 Иваново, Россия \\ ${ }^{\mathrm{b}}$ Нижегородский наџиональный исследовательский университет им. Н.И. Лобачевского, 603950 Нижний Новгород, \\ Россия \\ ${ }^{\circledR}$ E-mail: stuzhin@isuct.ru
}

\begin{abstract}
Новый Sе-содержащий гетероииклический аналог субфталоцианина - (1,2,5-селенадиазоло)дибензосубпорфиразинатобор(III) хлорид 3 а синтезирован темплатной сочикломеризацией 1,2,5-селенадиазоло-3,4дикарбонитрила 1 и фталонитрила 2 a в присутствии $\mathrm{BCl}_{3}$ в n-ксилоле. Аналогично из динитрила 1 и тетрафтор- или тетрахлорфталонитрилов (2b или 2c) были получены октафтор- и октахлорзамещённые субпорфиразины $3 \boldsymbol{b}$ и 3c. Образование 3а-с установлено на основании данных MALDI-TOF масс-спектрометрии, а структура 3 a определена при помощи рентгено-структурного анализа. Обсуждается влияние галогенирования на спектральные свойства.
\end{abstract}

Ключевые слова: Аналоги субфталоцианина, субпорфиразины, 1,2,5-селенадиазол, перфторированные и перхлорированные производные, комплексы бора(III), кристаллическая структура, электронные спектры поглощения. 
Subphthalocyanines - phthalocyanine analogues containing a contracted macrocycle consisting of three isoindole units ${ }^{[1]}$ are actively studied in the last decades ${ }^{[2,3]}$ especially due to their potential application in organic electronics. ${ }^{[4]}$ While subphthalocyanines with non-substituted benzene rings are usually used as donor $p$-type layers in photovoltaic cells, ${ }^{[5]}$ their halogenated derivatives can serve as effective $n$-type acceptor materials. ${ }^{[6]}$ Another way to endow phthalocyanine dyes with high electron affinity is heteroatom substitution in benzene rings. Recently heterocyclic subphthalocyanine analogues containing fused pyrazine or 1,2,5-thiadiazole ring(s) instead of benzene rings have been reported in our works. ${ }^{[7-9]}$ The properties of their vacuum-sublimed thin films and prototypes of photovoltaic cells have been also presented in a preliminary communicaton. ${ }^{[10]}$ The energy level of the frontier molecular orbitals in phthalocyanine-type dyes and gap between them is important parameters determining the performance of these materials in organic electronic devices. ${ }^{[1]}$ It was also shown that substitution of $\mathrm{S}$ by Se in the 1,2,5-chalcogenadiazole ring fused to porphyrazine macrocycle can tune the MO energy levels what leads to the bathochromic shift the maximum of the lowest $\pi-\pi^{*}$ absorption band ${ }^{[12,13]}$ due to stronger destabilization of HOMO than LUMO. ${ }^{[14]}$ The presence of fused 1,2,5-selenadiazole rings which can be cleaved also opens various facilities of the peripheral modification of the macrocycle. ${ }^{[15]}$ Recently subporphyrazine containing three annulated 1,2,5-selenadiazole rings have been prepared, ${ }^{[9]}$ but very low yield and instability prevent the further investigation. Here we report the synthesis, spectral properties of subporphyrazine containing one 1,2,5-selenadiazole ring and two benzene rings and its perfluorinated and perchlorinated derivatives, and single crystal X-ray structure of non-halogenated compound.

Boron trichloride $(3 \mathrm{~mL}$ of $1 \mathrm{M}$ solution in $p$-xylene, Aldrich) was added to freshly sublimed 1,2,5-selenadiazole-3,4-dicarbonitrile ${ }^{[16]} \quad \mathbf{1}(2 \mathrm{mmol})$ and phthalonitrile 2 (1 mmol) (Scheme 1). The reaction mixture was refluxed for $1.5 \mathrm{~h}$, then it was placed on column filled with silica and chromatographed with $\mathrm{CH}_{2} \mathrm{Cl}_{2}$ to remove yellow byproducts and unreacted dinitrile. After addition of $10 \% \mathrm{THF}$ the dark violet fraction containing mixture of subphthalo-

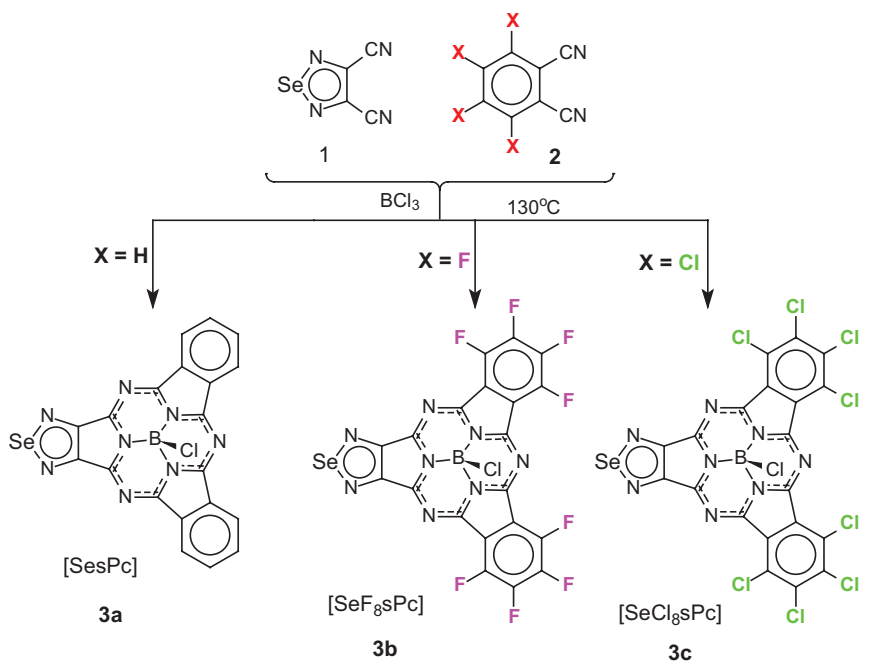

Scheme 1. cyanine dyes was eluted. Following gradual chromatography on silica with $\mathrm{CH}_{2} \mathrm{Cl}_{2}$-hexane mixture afforded subphthalocyanine as the $1^{\text {st }}$ rose fraction and its Se-containing analogue [SesPc] 3a as the $2^{\text {nd }}$ violet fraction. When tetrafluoro- or tetrachlorophthalonitriles (2b or $\mathbf{2 c}$ ) were used in a similar synthetic and isolation procedure the $1^{\text {st }}$ rose-pink fraction obtained in the course of column chromatography contained perfluorinated or perchlorinated subphthalocyanines, $\left[\mathrm{F}_{12} s \mathrm{Pc}\right]$ or $\left[\mathrm{Cl}_{12} s \mathrm{Pc}\right]$, and the $2^{\text {nd }}$ violet fraction - octafluoro- or octachlorodibenzo(1,2,5-selenadiazolo)subporphyrazines, $\left[\mathrm{SeF}_{8} s \mathrm{Pc}\right] \mathbf{3 b}$ or $\left[\mathrm{SeCl}_{8} s \mathrm{Pc}\right] \mathbf{3 c}$ (Scheme 1).

The results of the LDI-TOF mass-spectrometry confirm formation and isolation of subphthalocyanine analogues containing fused 1,2,5-selenadiazole fragment instead of one benzene ring (Figure 1). LDI-TOF mass-spectrum of the product obtained from phthalonitrile contains the positive molecular ion peak $[\mathrm{M}]^{+}$at $486 \mathrm{Da}$ and fragmentation ion $[\mathrm{M}-\mathrm{Cl}]^{+}$at $451 \mathrm{Da}$ confirming formation of 1,2,5-selenadiazolosubporphyrazine with two fused nonsubstituted benzene rings [SesPc]. For subporphyrazines obtained from halogenated phthalonitriles the intense molecular ion peaks can be observed only in the negative modes reflecting their strong electron affinity.

In the LDI-TOF mass-specrum of octafluorinated subporphyrazine $\left[\mathrm{SeF}_{8} s \mathrm{Pc}\right] \mathbf{3 b}$ a weak molecular ion peak $[\mathrm{M}+\mathrm{H}]^{-}$at $631 \mathrm{Da}$ is accompanied by much stronger deselenated anion [M-Se+H] $]^{-}$at $551 \mathrm{Da}$. Mass-spectrum of octachlorinated subporphyrazine $\left[\mathrm{SeCl}_{8} s \mathrm{Pc}\right] \mathbf{3 c}$ recorded using cyanohydroxycinnamic acid as a matrix contains intense molecular ion peak $[\mathrm{M}+\mathrm{H}]^{-}$at $763 \mathrm{Da}$ and less intense deselenated anion $[\mathrm{M}-\mathrm{Se}+\mathrm{H}]^{-}$at $683 \mathrm{Da}$. The observed and theoretical isotopic distribution of all peaks are in perfect correspondence (Figure 1, inserts).

UV-Vis spectra of the obtained 1,2,5-selenadiazolodibenzoporphyrazines contain three absorption maxima arising from $\pi-\pi^{*}$ electronic transition (Figure 2). The long-wave band at 595-610 $\mathrm{nm}$ can be assigned to the HOMO $\rightarrow$ LUMO transition and the band at $507-517 \mathrm{~nm}$ to the $\mathrm{HOMO} \rightarrow \mathrm{LUMO}+1$ transition. They can be denoted as $\mathrm{Q}_{1}$ and $\mathrm{Q}_{2}$ components of the split Q-band typical for subphthalocyanines-type dyes. The maxima of the long-wave $\mathrm{Q}_{1}$-band is observed at $595 \mathrm{~nm}$ for [SesPc] and fluorinated derivative $\left[\mathrm{SeF}_{8} s \mathrm{Pc}\right]$ and shifted bathochromically to $610 \mathrm{~nm}$ for chlorinated species $\left[\mathrm{SeCl}_{8} s \mathrm{Pc}\right]$. In the case of symmetrically substituted subphthalocyanines and suborphyrazines two LUMO are degenerated and the spectra contain a single Q-band (563 nm for unsubstituted subphthalocyanines [sPc]). The position of the Q-band is slightly shifted bathochromically for perfluorinated and perchlorinated derivatives $\left(\left[\mathrm{F}_{12} s \mathrm{Pc}\right]-574 \mathrm{~nm},\left[\mathrm{Cl}_{12} s \mathrm{Pc}\right]-569 \mathrm{~nm}^{[2]}\right)$, and for subporhyrazine $\left[\mathrm{Se}_{3} \mathrm{Pc}\right]$ with three 1,2,5-selenadiazole rings $\left(574 \mathrm{~nm}^{[9]}\right)$. Fusion of one 1,2,5-selenadiazole and two benzene rings leads to strong polarization of the $\pi$-chromophore and causes appearance of the split Q-band. It is interesting that the halogenation of benzene rings increases the splitting of the Q-band in Se-containing subporphyrazines $\left(2570 \mathrm{~cm}^{-1}\right.$ for $[\mathrm{SesPc}], 2900 \mathrm{~cm}^{-1}$ for $\left[\mathrm{SeF}_{8} s \mathrm{Pc}\right], 2950 \mathrm{~cm}^{-1}$ for $\left.\left[\mathrm{SeCl}_{8} s \mathrm{Pc}\right]\right)$ and its value is much larger than that observed for $\mathrm{S}$-containing species (554 and $578 \mathrm{~nm}, 780 \mathrm{~cm}^{-1}$ for $\left[\mathrm{SF}_{8} s \mathrm{Pc}\right]^{[7 b]}$ ).

Less intense absorption band at $435-450 \mathrm{~nm}$ is absent in the spectra of subphthalocyanine and its halogenated 

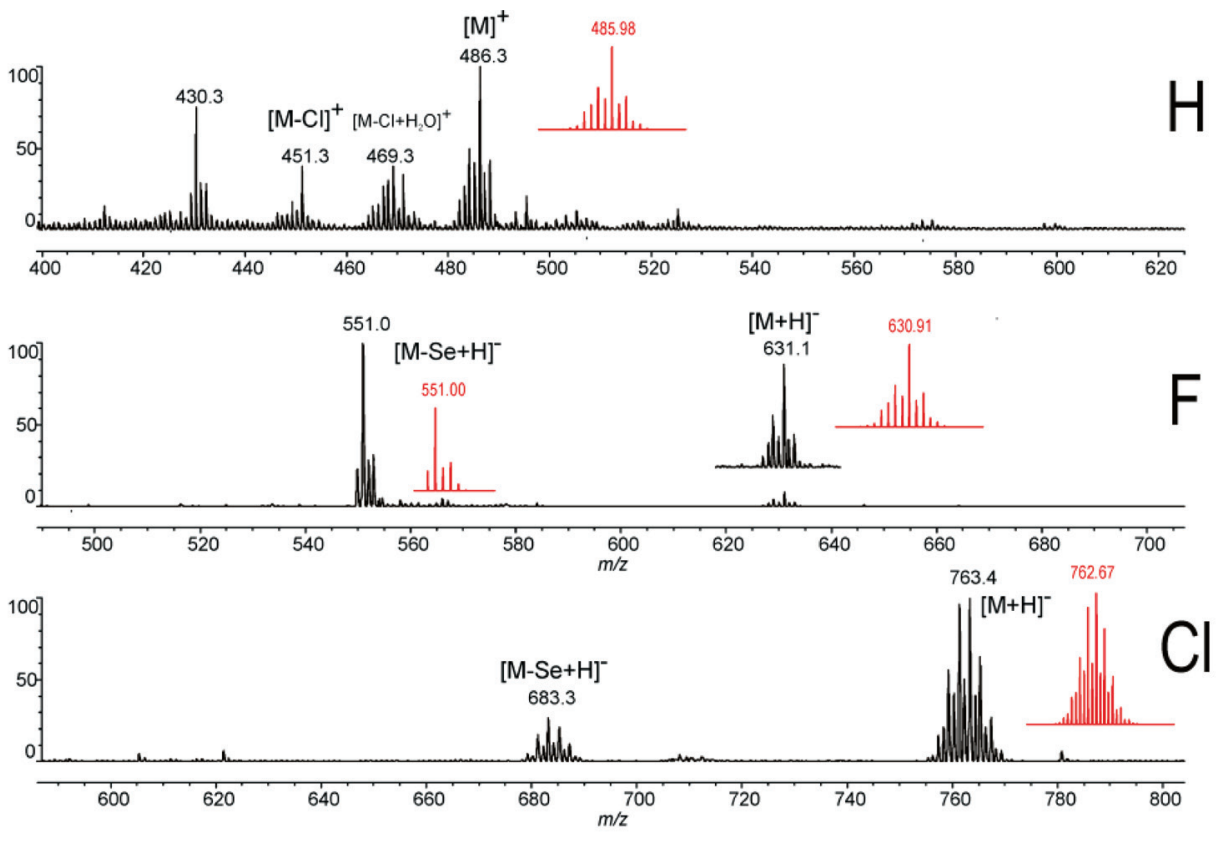

Figure 1. LDI-TOF mass-spectra of 1,2,5-selenadiazolodibenzosubporphyrazine (H), and its perfluorinated $(\mathrm{F})$ and perchlorinated $(\mathrm{Cl})$ derivatives. Spectra recorded in the positive $(\mathrm{H})$ and in the negative $(\mathrm{F}, \mathrm{Cl})$ modes without matrix $(\mathrm{H}, \mathrm{F})$ and with $\mathrm{CHCA}$ matrix $(\mathrm{Cl})$. Theoretical isotope distribution patterns of the molecular ions are shown as red inserts.

derivatives, but appearance of this additional band is a typical feature for subporphyrazines containing fused electrondeficient 1,2,5-thiadiazole or 1,2,5-selenadiazole rings $\left(415 \mathrm{~nm}\right.$ for $\left[\mathrm{SF}_{8} s \mathrm{Pc}\right], 390 \mathrm{~nm}$ for $\left[\mathrm{S}_{3} s \mathrm{Pc}\right]^{[7]}$ and $408 \mathrm{~nm}$ for $\left.\left[\mathrm{Se}_{3} s \mathrm{Pc}\right]^{[9]}\right)$. It was shown ${ }^{[9]}$ that this band is associated with electronic transition from HOMO to unoccupied $\pi-\mathrm{MO}$ localized predominantly on the fused heterocyclic rings and can be considered as a charge transfer transition.

The structure of non-halogenated Se-containing subporphyrazine [SesPc] was determined by X-ray diffraction study of single crystal obtained by slow evaporation of its solution in $\mathrm{CH}_{2} \mathrm{Cl}_{2}{ }^{\S}$ The molecule has a bowl-shaped structure typical for subphthalocyanines. In a crystal it has a symmetry plane passing through chlorine, boron and one

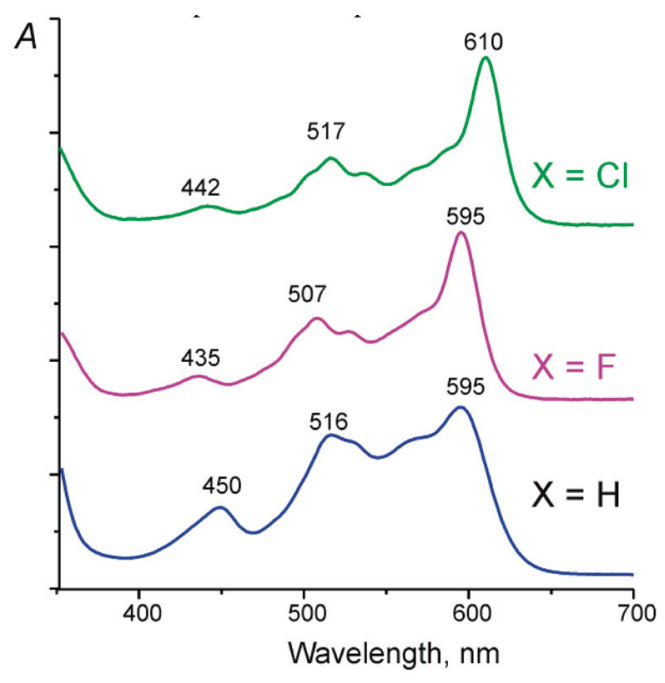

Figure 2. UV-Vis spectra of 1,2,5-selenadiazolodibenzosubporphyrazine and its perfluorinated and perchlorinated derivatives in $\mathrm{CH}_{2} \mathrm{Cl}_{2}$. of the coordinating nitrogen atoms (C11-B1-N1 plane). The boron atom has a tetrahedral coordination forming bonds with chlorine and three internal nitrogen atoms (bond length in $\AA$ : B1-Cl1 - 1.872; B1-N1 1.466 and B1-N2 1.479). It is located at $0.565 \AA$ above the plane formed by three coordinating nitrogen atoms.

In the crystal the molecules form stacks typical for subphthalocyanines bearing strong electron acceptor substituents (Figure 4). The important feature of the crystal structure is the disorder of the fused benzene and 1,2,5-selenadiazole rings. The molecule in the stacks are rotated around B1-Cl1 bond. Very likely this disorder is determined by $\pi \pi$ interactions between the benzene rings in the molecule in one stack and 1,2,5-selenadiazole ring in the molecule in a neighboring stack. The shortest intermolecular interatomic contacts are observed between the carbon atoms in $\beta$-pyrrole posi-

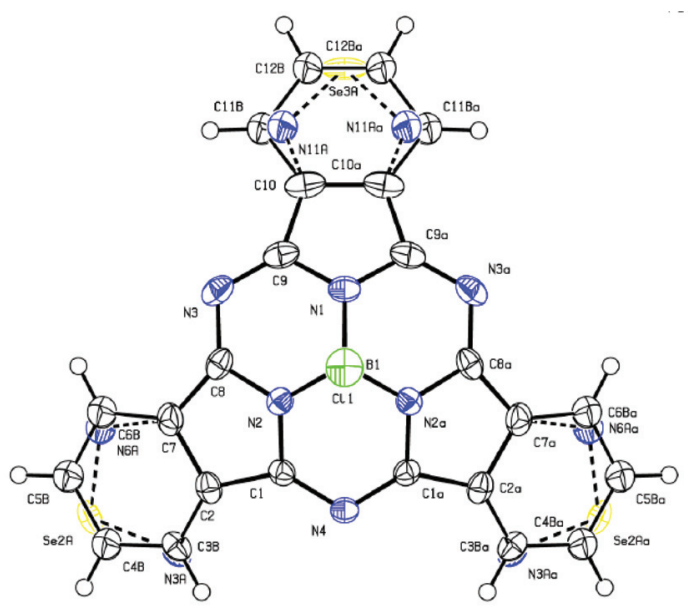

Figure 3. Molecular structure of 1,2,5-selenadiazole annulated subporphyrazine [SesPc]. 


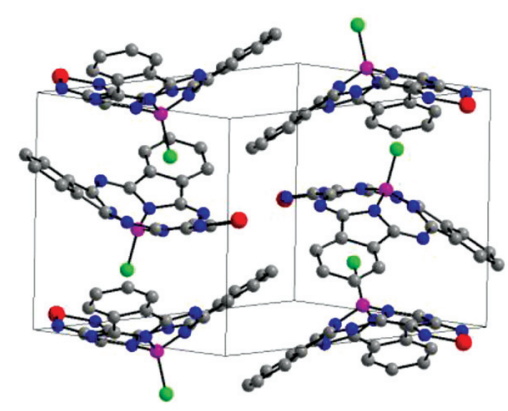

Figure 4. Molecular packing of 1,2,5-selenadiazole annulated subporphyrazine [SesPc].

tions with non-peripheral carbons of benzene rings (e.g. C7...C $3 \mathrm{~B}-3.496 \AA$; C2...C6B - $3.676 \AA$ ) and with nitrogen atoms of 1,2,5-selenadiazole rings (C2 ...N6A - $3.638 \AA$; C7...N3A - $3.696 \AA$ ). In addition short interatomic contacts due to VdW interaction are observed between Se3A atom in one molecule and meso-nitrogen atom N4 in the molecule in another stack. Such type of molecular arrangement might facilitate electron transfer processes between neighboring stacks and can be favorable for semiconducting properties.

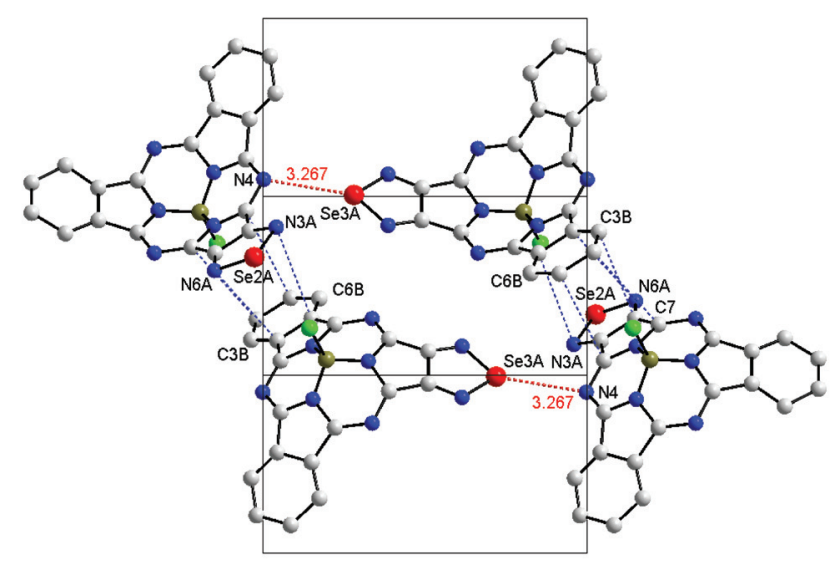

Figure 5. View along [1.2.0] axis showing intermolecular interactions in crystalline 1,2,5-selenadiazolodibenzosubporphyrazine [SesPc]. Van der Waals interactions Se3A...N4 are shown by red dashed lines. Short interatomic contacts $(<3.6 \AA)$ due to $\pi \pi-$ interaction between 1,2,5-selanadiazole fragment containing Se2A and benzene ring attached to $\mathrm{C} 2 \mathrm{C} 7$ are shown by blue dashed lines.

In conclusion, we have prepared and characterized a series of novel subphthalocyanine analogues which contain 1,2,5-selenadiazole fragment fused instead of one benzene ring. These molecules can be considered as perspective acceptor materials for application in organic electronics and the presence of 1,2,5-selenadiazole ring allows further structural modification of the macrocycle.

Acknowledgements. This work was supported by Russian Science Foundation (grant 17-13-01522).

\section{Notes and References}

$\S$ Structural data have been deposited in Cambridge Crystallographic data Center CCDC\#1971769.

1. (a) Meller A., Ossko A. Monatshefte für Chemie 1972, 103, 150; (b) Kietaib H. Monatshefte für Chemie 1974, 105, 405.

2. (a) Claessens C.G., González-Rodríguez D., Torres T. Chem. Rev. 2002, 102, 835-853; (b) Claessens C.G., GonzálezRodríguez D., Rodríguez-Morgade M.S., Medina A., Torres T. Chem. Rev. 2014, 114, 2192-2277.

3. Tolbin A.Yu., Tomilova L.G. Russ. Chem. Rev. 2011, 80, 531-551.

4. (a) Morse G.E., Bender T.P. ACS Applied Materials and Interfaces 2012, 4, 5055-5068; (b) Grant T.M., Josey D.S., Sampson K.L., Mudigonda T., Bender T.P., Lessard B.H. Chemical Record 2019, 19, 1093-1112.

5. Dearden C.A., Walker M., Beaumont N., Hancox I., Unsworth N.K., Sullivan P., McConville C.F., Jones T.S. Phys. Chem. Chem. Phys. 2014, 16, 18926-18932.

6. (a) Sullivan P., Duraud A., Hancox I., Beaumont N., Mirri G., Tucker J.H.R., Hatton R.A., Shipman M., Jones T.S. $A d v$. Eng. Mater. 2011, 1, 352-355; (b) Gommons H., Aernouts T., Verreet B., Heremans P., Medina A., Claessens C.C., Torres T. Adv. Funct. Mater. 2009, 19, 3435-3439.

7. (a) Hamdoush M., Ivanova S.S., Pakhomov G.L., Stuzhin P.A. Macroheterocycles 2016, 9, 230-233; (b) Hamdoush M., Skvortsov I.A., Mikhailov M.S., Pakhomov G.L., Stuzhin P.A. J. Fluorine Chem. 2017, 204, 31-36.

8. Stuzhin P.A., Skvortsov I.A., Zhabanov Y.A., Somov N.V., Razgonyaev O.V., Nikitin I.A., Koifman O.I. Dyes Pigm. 2019, 162, 888-897.

9. Hamdoush M., Nikitin K., Skvortsov I., Somov N., Zhabanov Yu., Stuzhin P.A. Dyes Pigm. 2019, 170, 107584.

10. Pakhomov G.L., Travkin V.V., Hamdoush M., Zhabanov Yu.A., Stuzhin P.A. Macroheterocycles 2017, 10, 548-551.

11. Cnops K., Zango G., Genoe J., Heremans P., Martinez-Diaz M.V., Torres T., Cheyns D. J. Am. Chem. Soc. 2015, 137, 8991-8997.

12. (a) Kudrik E.V., Bauer E.M., Ercolani C., Chiesi-Villa A., Rizzoli C., Gaberkorn A., Stuzhin P.A. Mendeleev Commun. 2001, (2), 45-47; (b) Stuzhin P.A., Pimkov I.V., Ul-Haq A., Ivanova S.S., Popkova I.A.,Volkovich D.I., Kuzmitskii V.A., Donzello M.-P. Russ. J. Org. Chem. 2007, 43, 1854-1863 [Zh. Org. Khim. 2007, 43, 1848-1857 (in Russ.)]; (c) Solovyov K.N., Stuzhin P.A., Kuzmitsky V.A., Volkovich D.I., Knyukshto V.N., Borisevich E.A., U1-Haque A. Macroheterocycles 2010, 3, 51-62.

13. (a) Knyukshto V.N., Volkovich D.I., Gladkov L.L., Kuz'mitskii V.A., Ul-Haque A., Popkova I.A., Stuzhin P.A., Solovyov K.N. Opt. Spectrosc. 2012, 113, 359-375 [Optika i Spektroskopiya 2012, 113, 401-417 (in Russ.)]; (b) Svec J., Zimcik P., Novakova L., Rakitin O.A., Amelichev S., Stuzhin P.A., Novakova V. Eur. J. Org. Chem. 2015, 2015, 596-604.

14. Zhabanov Yu.A., Tverdova N.V., Giricheva N.I., Girichev G.V., Stuzhin P.A. J. Porphyrins Phthalocyanines 2017, 21, 439-452.

15. (a) Kozlov A.V., Stuzhin P.A. Russ. J. Org. Chem. 2013, 49, 913-921 [Zh. Org. Khim. 2013, 49, 928-935 (in Russ)]; (b) Kozlov A.V., Stuzhin P.A. Macroheterocycles 2014, 7, 170-173.

16. Bauer E.M., Ercolani C., Galli P., Popkova I.A., Stuzhin P.A. J. Porphyrins Phthalocyanines 1999, 3, 371-380. 